\title{
Field-Portable Immunoassay Instruments and Reagents to Measure Chelators and Mobile Forms of Uranium
}

\author{
Blake, Diane A. \\ Tulane University
}

RESULTS TO DATE: Field Portable Immunoassay Instruments and Reagents to Measure Chelators and Mobile Forms of Uranium

Diane A. Blake, Principal Investigator Tulane University School of Medicine

Most recent report of results to date:

Previous studies from our laboratory have demonstrated the feasibility of immunoassays for identification and quantification of specific metal ions. Our ultimate goal for this project is to 1) isolate and characterize antibodies that recognize the most mobile form of uranium, $\mathrm{UO} 22+; 2$ ) assemble, test, and validate a new field-portable immunosensor based on these antibodies; 3) prepare new monoclonal antibodies to the primary chelators (EDTA and DTPA) found in DOE wastes.

+ The binding characteristics of two monoclonal antibodies that recognize chelated forms of uranium have been studied; the results of these analyses are summarized in the table below.

Characteristic Antibody 8A11 Antibody 12F6 Kd, DCP(M) 3.0 x 10-4 7.5 x 10-7 Kd, U022+DCP(M) $5.5 \times$ 10-9 9.1 x 10-10 Kon,U022+DCP 1.9 x 1072.0 x 107 (M-1s-1) Koff,U022+-DCP 1.05 x 10-1 1.8 x 10-2 (s-1) Limit $1.0 \mathrm{nM}$ (238ppt) $0.2 \mathrm{nM}$ (48 ppt) of Detection (DCP is 2,9-dicarboxyl-1,10-phenanthroline)

+ The 8A11 antibody was chosen for further instrument development studies.

Based on these results, we initially began our instrument development studies with antibody 12F6, because it bound more tightly to the U022+-DCP complex. However, the chemistry required to covalently attach a fluorescent tag to the protein completely destroyed the ability of $12 \mathrm{~F} 6$ to bind to the U022+-DCP complex. Subsequently, we determined that the $8 \mathrm{~A} 11$ antibody retained $100 \%$ of its activity after conjugation with a fluorescent marker. Antibody 8A11 was therefore chosen for subsequent instrument development work.

+ The prototype disposable cassettes to be used in the final instrument have been extensively tested with the bench top prototype instrument. A prototype immunoassay has been developed with these cassettes and the bench top instrument that can detect U022+ at less than $10 \mathrm{nM}$.

All of the cassettes provided by Sapidyne Instruments showed significant and different background fluorescence that decayed over time. The largest changes in the fluorescence occurred within the 1st hr of illumination, and stable data could be obtained by illuminating the cassettes for 1 hour before beginning any experiments. A prototype assay for U022+ was assembled using fluorescently labeled 8A11 antibody and a capture reagent composed of rigid beads absorption-coated with an U022+-DCP-protein conjugate. The bench top instrument was able to easily distinguish between samples that contained $3 \times 10-4 \mathrm{M} \mathrm{DCP}$ from those that contained $3 \times 10-4 \mathrm{M} \mathrm{DCP}$ plus $8.0 \times 10-9 \mathrm{M} \mathrm{U022+.}$ 
+ An engineering meeting in New Orleans with the president of Sapidyne Instruments has resulted in design changes that should significantly improve the performance of the final instrument.

After extensive discussions with Steve Lackie of Sapidyne Instruments, Inc. we have decided to modify the design of the handheld instrument so that we will ultimately have the ability to illuminate the sample cassette with two different wavelengths of light. This design change will permit us to include a positive control for each environmental sample and should significantly reduce the number of false positives in the final immunoassay. This new design change will delay the arrival of the final prototype instrument from September, 2000 to December, 2000, and permission is sought to rollover the funds for instrument purchase $(\$ 75,000)$ originally budgeted in Year 02 of the project to Year 03. Both the cassettes and the bench top instrument have been sent back to Sapidyne Instruments for redesign. The redesign will include changing the light source in the bench top instrument and the changing the plastic from which the cassettes were manufactured.

DELIVERABLES: Most recent products delivered:

\section{Presentations}

D.A. Blake, R.C. Blake, II, H. Yu, and A. R. Pavlov (2000) "Antibodies and Antibody-based Sensors for Hexavalent Uranium and Chelators", DOE-NABIR PI Workshop, Reston, VA, Jan. 31-Feb. 2.

D.A. Blake, A. R. Pavlov, H. Yu, M. Khosraviani, H.E. Ensley, and R.C. Blake, II (2000) "Antibodies and antibody-based immunosensors for hexavalent uranium", Invited Presentation, 219th ACS National Meeting, San Francisco, CA, March 26-30. (Our presentation at this meeting was featured in the June 2000 issue of Inside Laboratory Management, pp. 27-28, in an article highlighting the future of analytical instrumentation.)

D.A. Blake, R.C. Blake II, H. Yu, (2000) "Antibody-based sensors for heavy metal ions", Sixth World Congress on Biosensors, San Diego, CA, May 24-26. (This abstract was chosen by the organizers of the conference for inclusion as a full paper in Biosensors and Bioelectronics.)

Publications

D.A. Blake, A.R. Pavlov, M. Khosraviani, R.C. Blake II, and G.C. Flowers (2000) "Immunoassays as an alternative method for the analysis of heavy metals in environmental samples", in Immunoassays: Methods and Protocols, Ed. A.L. Ghindilis, A.R. Pavlov, and P.B. Atayosov. Series title: Methods in Molecular Biology, Humana Press, Inc., Totowa, New York, in press.

R.C. Blake II and D.A. Blake (2000) "A new method to study high affinity binding interactions in homogeneous solutions: Flow fluorimetry using the KinExA immunoassay instrument", in Immunoassays: Methods and Protocols, Ed. A.L. Ghindilis, A.R. Pavlov, and P.B. Atayosov. Series title: Methods in Molecular Biology, Humana Press Inc. Totowa, New York, in press.

D.A. Blake, A.R. Pavlov, H. Yu, M. Khosraviani, H.E. Ensley, and R.C. Blake II (2000) "Antibodies and antibody-based assays for hexavalent uranium", Anal. Chim. Acta, submitted.

D.A. Blake, R.C. Blake II, A.R. Pavlov, R.M. Jones, I.A.M. Darwish, and H. Yu (2000) "Antibody-based sensors for heavy metal ions", Biosensors and Bioelectronics, submitted. 